\title{
PUBLICISTICA LUI LIVIU REBREANU
}

\begin{abstract}
Alina DORLE ${ }^{*}$
\section{Liviu Rebreanu's Journalism}

Abstract: Liviu Rebreanu is a strong intellectual presence and, at the same time, enjoyed a great social prestige. His literary talent and work capacity have ensured a spectacular critical reception and a great public success.

Without a political engagement and ideological involvement, the journalist Liviu Rebreanu records with an acute observation sense the dynamic rhythms of the social and political life in interwar Romania: the succession in power of political parties, the pros and cons of parliamentary democracy, the crisis of capitalism, the mirage of western forms, the apparition and development of extreme ideological phenomena and the development and downfall of the royal dictatorship.
\end{abstract}

Keywords: writer, journalist, journalism, ideology, parliamentarism, politics

Anii '30 îl înfăţişează pe Liviu Rebreanu ca pe o prezenţă intelectuală puternică, beneficiind de un statut de excelenţă în cadrul breslei scriitoriceşti şi de un prestigiu social în continuă consolidare.

În plan literar, Rebreanu se afirmase ca inovator al romanului românesc modern ce surprinde problematica psiho-socială complexă a ţăranului român şi îşi dobândise renumele de fin observator al mecanismelor socio-politice de la început de secol XX, urmărind, dincolo de aspectele unui realism obiectiv cu caracter de frescă, dinamica interioară a spiritualităţii româneşti şi a mentalului colectiv popular, surprins în angrenajul transformărilor şi tendinţelor epocii. Talentul literar şi capacitatea de muncă, receptarea critică spectaculoasă, succesul uriaş pe care 1-a avut la public, constant şi fără emoţia diminuării tirajelor - este de remarcat faptul că Rebreanu se numără printre puţinii scriitori care au putut să-şi asigure existenţa materială din această meserie - i-au fixat ferm locul în elita socio-culturală interbelică. Astfel, între 1926-1932, Rebreanu deţine funcţia de Preşedinte al Societăţii Scriitorilor Români, în decembrie 1929 este ales director al Teatrului Naţional din Bucureşti (o funcţie mult râvnită în acei ani, tocmai prin faptul că teatrul reprezenta un prim focar de efervescenţă cultural-mondenă), cunoscând însă, cu acest prilej, disconfortul numeroaselor atacuri şi scandaluri de presă. ${ }^{1}$ Numirea în conducerea unor

\footnotetext{
* Lector asociat dr., Facultatea de Litere, Universitatea Tehnică Cluj-Napoca, str. Victoriei nr. 76, Baia Mare.

${ }^{1}$ Conflictele cu Nichifor Crainic sau cu Pamfil Şeicaru sunt amintite frecvent în jurnalele şi insemnările sale memorialistice.
} 
proiecte de organizare şi dezvoltare a culturii şi artei, sub titulatura de Direcţia Educaţiei Poporului, din iniţiativa lui Iuliu Maniu, prim-ministru în aceea perioadă, înteţeşte atacurile vehemnente la adresa scriitorului.

Tot mai dezamăgit de dificultăţile întâmpinate în culisele scenei politice şi culturale bucureştene - aspect care constituie de altfel geneza romanului Gorila - se retrage în anii următori pe făgaşurile creaţiei literare şi se implică activ în colaborarea şi conducerea unor reviste culturale din epocă (este director al revistei România literară, colaborator al revistelor Adevărul literar şi artistic, Viaţa românească, Gazeta literară, România etc.), conferenţiază în cadrul Astrei sau participă la diferite congrese internaţionale, de tipul PEN-Club sau în Londra, ca vicepreşedinte al Radiodifuziunii Române. După repetate tergiversări, destul de frustrante pentru scriitor, este ales membru al Academiei Române în 1939, moment care îi aureolează superlativ prestigiul şi îi încoronează activitatea intelectuală.

În climatul controversat al epocii, când intelectualii, în cvasitotalitatea lor, adoptau anumite poziţii şi atitudini politice, iar cei mai mulţi se raliau la structurile ideologice consacrate, Liviu Rebreanu se consacră cu desăvârşire unei obiectivităţi principiale, căreia îi rămâne fidel pe tot parcursul sinuos al traiectoriei istorice, limitându-se la asumarea unui rol de observator detaşat, neutru al fenomenelor socio-politice şi culturale. Este în fond aplicarea în plan social a aceluiaşi principiu al obiectivităţii naratologice, al perspectivei detaşate, pe care Rebreanu şi-1 asumă nu doar în domeniul literar, ci şi în viaţa publică, în poziţiile luate în faţa evenimentelor politice şi sociale sau chiar în elementaritatea gândirii sale conceptuale: „Scriitorul - afirmă autorul într-un interviu ${ }^{2}-$ să fie deschis evenimentelor şi vieţii din afară ; $s \breve{a}$ se lase impresionat de ele, emoţionat chiar. Fără să li se robească..". Neangajat politic şi neimplicat ideologic, în manifestările sale ca scriitor, fie literare, fie jurnalistice - biografii şi exegeţii săi, amintesc frecvent de rezistenţa acerbă a scriitorului în faţa oricăror ispite electorale ${ }^{3}-$ Liviu Rebreanu priveşte din exterior şi înregistrează cu un acut simţ al observaţiei, tumultuozitatea vieţii politice şi sociale a României interbelice: perindarea intempestivă a partidelor politice la guvernare, avantajele şi minusurile democraţiei parlamentare, a capitalismului coercitiv, mirajul formelor occidentale atât de râvnite, apariţia şi dezvoltarea fenomenelor ideologice extremiste, cu toate consecinţele nefaste ale manifestării lor, ascensiunea şi degenerescenţa dictaturii carliste. Mai deplânge abaterea culturii române de la directivele spiritului naţional, dar şi proliferarea semidoctismului politic şi cultural, cauzator de decadenţă generală.

\footnotetext{
${ }^{2}$ Liviu Rebreanu, Jurnal II, Editura Minerva, 1984, p. 282.

${ }^{3}$ Niculae Gheran, Andrei Moldovan, Liviu Rebreanu prin el însuşi, Editura Academiei Române, Bucureşti, 2008, p. 61.
} 
Obiectivitatea sa emblematică îi asigură indubitabil libertatea în gândire şi neîngrădirea conştiinţei între limitele unor paradigme ideologice. Această situare îl fereşte de riscul denaturării realităţii factual istorice, prin pasiunea implicării, mai ales în contextul unor puternice pulsiuni colective, cum erau cele stârnite de acţiunile energice şi adesea violente de pe scena politică. Poziţia obiectivă a lui Rebreanu rezidă tocmai în non-atașamentul său la vreun partid sau program ideologic, fără a exclude însă prin aceasta, manifestarea unei doze de sensibilitate şi trăire simpatetică faţă de desfăşurărea evenimentelor care afectează destinului istoric al ţării. Desigur că această emoţie, concretizată deseori în speranţa şi încrederea acordată debutului unor fapte şi acţiuni politice, deturnată mai apoi, aproape invariabil, în dezamăgire profundă, nu trece dincolo de jurnalele sale intime, de operele memorialistice sau de câteva din interviurile acordate. De pildă, într-un interviu acordat lui Nicolae Gheran, Puia Florica Rebreanu ${ }^{4}$ vorbeşte deschis despre neutralitatea şi lipsa angajamentul politic, ca mentalitate structurală și atitudine constantă a scriitorului: „Tatăl meu a fost în afara oricărui cadru de partid. Nu şi-a făcut din crezul său artistic nici un act de adeziune la vreo mişcare poltică a vremii lui. Isşi reclama o independenţă de gândire pe care, în mai toate cazurile, o şi teoretiza ca general valabilă creatorilor din sfera artei. Politicianismul î repugna. Asta nu însemană că se izola într-un turn de fildeş. Privea cu un ochi atent la tot ce-l înconjura, la schimbările politice şi sociale din actualitatea imediată, rezervându-şi dreptul de a extrage din cotidian numai ceea ce putea să-i nutrească imaginaţia creatoare. (...) Optimist, copilăros chiar, spera mai de fiecare dată ca programele formulate în epocă să fie benefice în istoria neamului. (...) rotaţia aceloraşi partide politice la cârma ţării începuse de mult să-l dezamăgească: alte acţiuni, lăturalnice, de opoziţie, frapante o clipă avau să-l amărească şi mai mult."

Chiar şi obiectivitatea în artă cunoaşte în viziunea romancierului o oarecare relativizare, ceea ce poate însemna o uşoară vibraţie emoţională în faţa realităţii transfigurate artistic în operă. El însuşi mărturiseşte: „Mă feresc să subliniez cu orice preț semnificaţia cutărei întâmplări în dauna alteia. Dar trebuie să mărturisesc că, în mod absolut, lucrul acesta nu este cu putinţă întotdeauna. Simpatia mea fie pentru o întâmplare, fie pentru un personagiu transpiră totuşi. Ea trece ca un fluid până în inima cititorului. Daca n-ar fi aşa, artistul ar fi un Dumnezeu. Dar nu e."5 Efectul implacabil al resorturilor psiho-emoţionale în evaluarea mediului de observaţie transpare şi in planul non-ficţionalului, în domeniul politic sau social. Remarcile şi consideraţiile autorului întrezărite printre paginile confesive sau chiar printre unele articole publicistice trădează un instinctual simţ al

\footnotetext{
${ }^{4}$ interviu publicat în Liviu Rebreanu, Jurnal II..., In loc de postfaţă, p. 386.

${ }^{5}$ Nicolae Gheran, Andrei Moldovan, op.cit., p. 301.
} 
ierarhizării valorilor şi al asumării cu pasiune a primatului spiritual naţional. Ideile şi concepţiile sale în raport cu realitatea istorică imediată se încadrează, dincolo de obiectivitatea invocată, în cadrele largi ale unui naţionalism primar, organic, elementar în configurarea identităţii naţionale de după Marea Unire şi în conturarea unui specific cultural care să valorifice plenar patrimoniul spiritualităţii româneşti.

Pornind de la ideea că ,romancierul trebuie să aibă un duh naţional”, să fie ,prins adânc cu întinse rădăcini de pământul unei ţări, din care-şi trage seva", Liviu Rebreanu ${ }^{6}$ reclamă necesitatea unui puternic spirit naţional în emanciparea ,neamului nostru tânăr în cultură" şi deschide prin aceasta directivele canalizării energiei creatoare înspre desăvârşirea ideii specificului naţional. Până la un moment dat, viziunea sa despre primatul spiritului naţional în opera de artă coincide cu cea a lui Octavian Goga, din perioada în care acesta milita fervent pentru întregirea şi pentru consolidarea spirituală a ţării nou formate. „Umblând prin Transilvania simţi la fiecare pas nevoia propagandei româneşti", după Unire. Prin urmare, acordă deocamdată credit activismului politic al poetului Cântecelor fără țară, în virtutea ideii că ,scriitorii au pregătit mai bine războiul unirii celei mari, decât politicianii şi militarii. Scriitorii au fost cercetaşii unirii. Scrisul lor a ţinut viu sentimentul românesc pretutindeni." ${ }^{8} \mathrm{Cu}$ toate acestea, el nu îşi reprimă nemulţumirea faţă de rezultatele minimale ale mandatului ministerial al confratelui său ardelean, reproşându-i incapacitatea de a rămâne în afara partizanatului politic.

El pledează pentru concertarea tuturor energiilor sufleteşti ale neamului pentru configurarea unui nivel creator şi al unui statut dinamic şi de impact al vieţii culturale care să se poată impune atât în contextul culturii europene, cât şi în faţa aportului cultural substanţial al minorităţilor naţionale ale României Mari: „Ţara noastră, devenind mare, a devenit şi un câmp de luptă pentru supremaţia culturală. Germanii, ungurii, ruşii ajunşi sub dominaţia românească nu vor fi cu adevărat dominaţi decât în ziua în care vor recunoaşte cel puţin egalitatea noastră culturală"" . Autorul îşi exprimă ideile cu francheţe, într-o vădită tentativă de direcţionare a atitudinii publice şi de educare a maselor, în vederea promovării culturii cu specific naţional. În acest sens, cartea românească ar putea fi şi ar trebui să fie - în opinia sa - mijlocul cel mai eficace pentru unificarea şi consolidarea sufletească a României noi" $"$.

\footnotetext{
${ }^{6}$ idem, pp. 264, 266.

${ }^{7}$ Liviu Rebreanu, Ministerul propagandei, în Opere 16, Insemnări de-o zi, Ed. Minerva, 1995, p. 176.

${ }^{8}$ idem, Octavian Goga, Ministru al Cultelor şi Instrucţiunii publice, în Opere 16...., p.179.

${ }^{9}$ Liviu Rebreanu, Artele şi Ministerul artelor, în Opere 16..., p. 200.

${ }^{10}$ idem, Direcţia literelor, în Opere 16..., p. 224.
} 


\section{Atiudini publicistice. Factorul naţional în cultură}

Este de remarcat faptul că opera publicistică a lui Rebreanu este în mare parte formată din articole cu o tematică literară variată, desfăşurată pe teritorii culturale întinse de la Nuvele japoneze, la Sarath Kumar Ghosh, Washington Irving sau Gorki şi până la numele consacrate ale culturii europene, cum ar fi Zola, Balzac, Tolstoi sau Nietzsche, oprindu-se sporadic şi asupra valorilor culturii nostre. Acestea sunt însă articole succinte, chiar lacunare, mici notaţii de lectură, fără pledoarii exagerate sau pretenţii exegetice exprese, dând adesea impresia de mici ,popasuri” printre ţări şi culturi. Există însă o serie de articole, cum ar fi Europenism sau Românism?, Cumplita nesimţire religioasă a poporului nostru?, Presa şi cultura, Xenofilie, Comploturi, Tradiţionalismul, Patria Româenască, Marea înviere, Moartea parlamentarismului şi altele care abordează teme socio-culturale şi politice, vizând în mod special realitatea frustă a anilor '30 şi '40. Aceste articole reflectă atitudinile şi poziţiile ferme ale autorului pentru afirmarea specificului naţional şi mai ales pentru formarea unei conştiinţe naţionale care să reverbereze benefic şi fecund în cultură şi în viaţa politică şi socială.

Opiniile şi dezideratele ce răzbat aici corespund îndeaproape viziunii idealiste şi spirituale a tinerei generaţii de intelectuali, intraţi cu prospeţime în dezbaterea de idei a anilor '20 - în mare parte, criterioniştii de mai apoi drept pentru care, până la un punct, mai exact până în momentul în care această grupare intelectuală alege activismul politic, ideile lui Rebreanu se armonizează cu concepţia despre misiunea noii generaţii, asumată fervent în termenii unui ideal spiritual românesc: emanciparea culturală a României, prin preeminenţa spiritului naţional.

Romancierul pledează aşadar pentru promovarea ideilor ce alcătuiesc în fond substanţa retorică a ideologiei de dreapta, cultivată acerb de către tinerii înflăcăraţi, fără însă a se ralia formal la activismul lor şi fără a face parte din structurile specifice generaţiei lor, nici măcar ca îndrumător sau inspirator, cum au fost de pildă Nae Ionescu sau Nichifor Crainic. Rebreanu nu se angajează în emiterea unor teorii politice sau concepte ideologice distincte- spiritul său creator rămâne fidel literaturii - dar atitudinile şi ideile sale răspund, prin prisma observaţiilor obiective, realităţilor sociale şi politice reclamate nestingherit de noua generaţie. În acest sens, articolele menţionate abundă în pledoarii pentru ideea specificului naţional, pentru respingerea internaţionalismului, a formelor occindentale ale capitalismului brutal sau pentru anihilarea corupţiei şi a politicianismului din sânul partidelor consacrate, pentru valorificarea tradiţiei ca pondere primordială în afirmarea civilizaţiei sau angajarea presei pe linia culturii naţionale. $\mathrm{Nu}$ îi este străină nici ideea, de succes în epocă, atât în cercurile de dreapta, cât şi 
în cele de stânga, a „omului nou”, ca deziderat-panaceu ce reclamă imperios schimbarea mentalităţii individuale şi colective.

În unele articole sporadice, ca de pildă în Asta-i literatură..., critica la adresa corupţiei şi a politicianismului veros se ascute într-o ironie usturătoare, frapantă, de-a dreptul neobişnuită pentru stilul autorului. Nervul sarcastic, care în acest articol aminteşte de retorica celor mai impetuoşi activişti ai extremei drepte, este vizibil accentuat: „Din nenorocire trăim în epoca Pşepelinsky. Sute şi mii de Pşepelinsky se lăfăiesc în averile stoarse de azi pe mâine, din favoruri politice sau din gheşefturi murdare, patronate şi încurajate de politică. Şi, de la înălţimea sacilor de bani, toţi Pşepelinsky se uită cu dispreț la cei jupuiţi de ei şi, simţindu-se la adăpost de orice primejdie, zbiară fără pudoare: - Asta-i literatură... pentru ceata de Pşepelinsky care, ca nişte lipitori, sug vlaga ţării, toate năzuinţele cinstite ale celor fără bani sunt...literatură. Fiindcă ei, în loc de suflet au burtă... (...) Neamul Pşepelinskilor stăpânesc în parlament şi în guvern şi în toate marile demnităţi ale ţării. Având puterea în mâini, au posibilitatea să se înmulțească în mod prodigios, să cuprindă în mrejele lor trecutul, prezentul şi viitorul, să pervertească însuşi sufletul poporului românesc. Încercările de impotrivire sunt dezarmate vertiginos în toate domeniile şi prin toate mijloacele. Idealul lor este să transforme, cât mai curând, România întreagă într-o imensă burtă fără cap...."11

Privirea scrutătoare a publicistului se opreşte şi asupra domeniilor profesionale în special asupra celor care au legătură directă cu domeniul cultural şi condamnă subordonarea lor la politic: „Profesorii nu sunt ai partidelor, ci ai ţării şi ai viitorului neamului" ${ }^{12}$ exclamă autorul în articolul foarte sugestiv intitulat Calvarul profesorilor. Pe acelaşi ton şi cu acelaşi simţ al obseravţiei critice, Rebreanu condamnă şi aservirea presei faţă de politic: „Politica a cucerit toate paginile ziarului românesc şi la noi, politica e sinonim cu ticăloşie, fiindcă e prezentă în toate fraudele, în toate relele." 13 Consecinţele directe ale acestui fenomen duc la răsturnarea valorilor şi la deturnarea rolului informativ al presei, chiar glisarea acestuia înspre o tendinţă manipulatoare, deoarece ,pe măsură ce politica, sub nenumăratele ei forme specific româneşti, acaparează presa, dispar din ce în ce preocupările culturale. (...) Gazetarul român de azi are, în general, un dispreț profund pentru orice problemă culturală. Ultimul reporteraş care de-abia poate concepe o informaţie anodină se crede mult superior celui mai bun scriitor." Şi astfel, din ceea ce presa ar fi trebuit să fie, în concepţia sa, şi anume „canalizatorul fericirii omeneşti”, căci „s-a născut din setea de cultură a mulţimii”. Ea devine „un redutabil factor de

\footnotetext{
${ }^{11}$ Liviu Rebreanu, Asta-i literatură, în Opere 16..., p. 206.

12 idem, Calvarul profesorilor, în Opere 16..., p. 212.

${ }^{13}$ idem, Presa şi cultura, în Opere 16 ...p. 223.

14 ibidem.
} 
descompunere socială."15 Autorul observă că factorul degenerator al valorii în presă este chiar îndepărtarea ei de scopurile iniţiale şi adoptarea strategiilor comerciale, de sorginte americană, care cultivă curiozitatea patologică a senzaţionalului, mai ales prin scandalurile politice sau mondene. În acest context, informaţia dobândeşte valoare doar dacă e „tăvălită în noroi”, iar presa nu mai poate fi altceva decât „o licitaţie vajnică inspre dibuirea tuturor josniciilor omeneşti." ${ }^{\prime \prime}$ Soluţiile propuse de autor pe un ton cald, condescendent, contrastând oarecum cu gravitatea analitică a articolului, orientează din nou opinia publică pe drumul, considerat izbăvitor, al culturii: „dând cuvenita atenţie frământărilor culturale, presa va fi cel mai puternic element de cultură şi cea mai bună călăuză a consolidării naţionale." 17 Temperarea vocii sarcastice în finalul articolelor sau găsirea unor soluţii care trimit invariabil la cultură sau la ameliorarea situaţiilor critice prin „o vorbă bună!”, căci „,bunătatea potoleşte pornirile nesocotite" ${ }^{\prime 1}$, devine o notă distinctivă a stilului său publicistic. Este o dovadă în plus a prudenţei şi a stăpânirii de sine instinctive a celui care scrutează minuţios realitatea care-1 înconjoară, supunând-o unei analize acerbe, fără a trece însă pragul afectiv al implicării totale.

Respingerea formelor occidentale de civilizaţie, chiar şi cea a europenismului, se află în viziunea lui Rebreanu în strânsă corelaţie cu ideea afirmării specificului naţional ca temelie în emanciparea şi dezvoltarea culturii române. Este factorul primordial care asigură în fond consolidarea spirituală a Unirii de la 1918 şi afirmarea identităţii naţionale ca destin istoric şi cultural în traiectoria existenţială a Europei momentului. Găsim aici un punct tangenţial cu viziunea lui Cioran asupra destinului unei culturi fără istorie care se naşte în umbra marilor civilizaţii şi care îşi reclamă dreptul la existenţă proprie.

Momentul istoric de după Unire, aureolat de vitalitatea şi entuziasmul juvenil al emancipării naţiunii ar corespunde cu ceea ce, peste câţiva ani, Cioran numeşte intrarea în istorie. „Neamul românesc de-abia îşi începe viaţa, azi iese la lumină ca un adolescent barbar, gol şi strălucitor de frumos" ${ }^{\prime 19}$ - exclamă încrezător romancierul. Rebreanu evidenţiază premisele spirituale, culturale şi civilizaţionale ale noii configuraţii statale, învederând ca prioritate valorificarea fibrei autentice a specificului naţional pur, arhaic, nepervertit de tentaţiile civilizaţiei occidentale şi animat de proiecţiile vizionare ale unei conştiinţe creatoare: Sufletul românesc nu porneşte din oraşele de operetă, pete de murdărie pe veşmântul curat al neamului. Oraşele româneşti se vor ridica din cultura românească, mâine

\footnotetext{
15 ibidem, p. 222.

16 ibidem, p. 223.

17 ibidem, p. 224.

${ }^{18}$ Liviu Rebreanu, Calvarul profesorilor, în Opere 16..., p. 213.

${ }^{19}$ idem, Zorile, în Opere 16..., p. 214.
} 
sau poimâine, simbolizând-o, reprezentând-o. Sufletul românesc porneşte spre viaţă din câmpiile, văile, munţii noştri unde s-a plămădit şi a suferit. Acolo sunt milioanele descătuşate din care izbucneşte irezistibil şi impetuos, naiv şi falnic... Mâine va clădi din nimic oraşe, şi catedrale, şi artă, şi ştiinţăa, toate potrivite cu firea lui adevărată, nouă, sănătoasă... sufletul românesc nu cunoaşte Occidentul, dar se simte în stare să se realizeze deplin printr-o viaţă proprie.",20

Entuziasmul prozatorului îşi are germenii într-un puternic impuls al conştiinţei Unirii care, înfăptuită ca un act fundamental politic, într-un context general european, necesită pentru consolidarea ei, un aport psihospiritual şi social considerabil, în stare să îi asigure coeziunea şi fiabilitatea. E un impuls natural, organic care apare ca un stimulent esenţial în mentalitatea epocii şi pe care, de altfel, 1-au cultivat şi teoretizat - în conceptele unei ideologii de nuanţă naţionalistă, asimilată ulterior de forţele de dreapta - tinerii intelectuali ai Generaţiei '30: „Cea dintâi misiune a tinerei generaţii - afirmă de pildă, unul din membrii ei de vază, filosoful Mircea Vulcănescu - este să asigure unitatea sufletească a românilor, uniţi politiceşte prin sacrificiul generaţiei de foc. Să şteargă deosebirile regionale în măsura în care înseamnă altceva decât nuanţarea unui aceluiaşi suflet naţional." 21

\section{Românism vs europenism}

Evocând „declinul Occidentului”, pe linia filosofiei lui Spengler, mult comentată în epocă, Rebreanu respinge cu vehemenţă influenţele civilizaţiei şi culturilor apusene, a căror decadenţă se resimte mai ales în scepticismul şi nihilismul modernităţii, perceput ca element nefast şi distrugător pentru evoluţia spirituală a unei culturi naţionale în creştere organică. ,, In Europa miroase a mort - constată emfatic publicistul, într-o peroraţie plauzibilă pe marginea unor notaţii de fillosofie a culturii. O lume se stinge după o viaţă glorioasă de un mileniu. (...) Şi acum obosită, istovită, fără credinţă adevărată, fără speranţe, cariată de scepticism, se zvârcoleşte în spasmurile agoniei"22 Drept pentru care, autorul pledează pentru primatul etnicului, ,izvorul vieţii noastre proprii" care ţâşneşte din ,adâncurile sufletului românesc". El sugerează, în nuanţe alegorice, efectele distructive ale occidentalismului asupra tinerei culturi naţionale: „nu mi-e ruşine de goliciunea noastră şi trebuie să ne mândrim cu barbaria care e diagnosticul sănătătzii nostre puternice. A ne agăţa de carul civilizaţiei apusene ar fi ca şi când am vrea să culcăm în patul somptuos al unui moşneag muribund pe un

\footnotetext{
20 idem, 215-216.

${ }^{21}$ Mircea Vulcănescu, Tânăra generaţie. Crize vechi în haine noi. Cine sunt şi ce vor tinerii români?, Editura Compania, Bucureşti, 2004, pp.72-73.

${ }^{22}$ Liviu Rebreanu, Zorile, în Opere 16..., p. 214.
} 
flăcău voinic de abia coborât din creierii munţilor." ${ }^{23} \mathrm{Cu}$ toate acestea, tentaţia occidentalizării este foarte mare şi generează indubitabil dileme şi ispite în rândul celor care „,̂ncă nu au conştiinţa puterilor neamului”, căci „ispitele apusului le stau în cale şi le împleticesc paşii...E o şovăire în toată viaţa românească, parcă ne-am simţi la o răscruce de drumuri şi n-am şti ce să alegem."24

Într-unul dintre articolele sale de primă importanţă, Europenism sau Românism, publicat în 1924, în revista Drum nou, Rebreanu accentuează entuziasmul augural al sufletului pur românesc şi capacitatea acestuia de a crea o cultură proprie distinctivă, reprezentativă pentru destinul istoric al poporului, căci ,viaţa unui neam înseamnă o cultură proprie, suficientă în toate domeniile. Prin ce realizează specific un popor, ia parte adevărată şi progresul omenirii." 25 În acest sens, autorul pare să combată teoriile sincronismului lovinescian, potrivit cărora culturile naţionale, în procesul lor evolutiv, prezintă necesitatea sincronizării cu literatura şi arta europeană, în virtutea ideii că ,valoarea artei nu stă în puritatea caracterului ei etnic, ci în alte condiţiuni estetice.",26

Liviu Rebreanu se poziţionează însă pe linia promovării autohtonismului ca bază a progresului culturii, cu toate implicaţiile acestuia vizând tradiţia, spiritualitatea religioasă, filosofia de viaţă a ţăranului român, mentalitatea arhaică. Este calea sigură de exprimare a sufletului românesc printr-o cultură viabilă care să asigure progresul, temelia civilizaţiei sau chiar universalismul, după cum crede Mircea Eliade. În accepţia lui Rebreanu, imitaţia Occidentului în oraşele româneşti nu este decât „o spoială ridicolă de civilizaţie”, „caricaturism occidental”. La fel cum şi aplicarea pe teren autohton a diferitelor sisteme economice, sociale sau politice împrumutate din Occident nu duce decât la încorsetarea spiritului nostru şi la reprimarea unei evoluţii naturale, organice: „Constituţia noastră belgiană, legile noastre franceze, parlamentarismul nostru britanic au rămas vorbe goale care se repetă papagaliceşte, la întruniri şi prin ziare; literatura şi artele, cu cât mai extravagante, cu cât mai izolate şi fără nici o înrâurire asupra celor cărora se adresează; democraţia noastră nu trăieşte decât în ideologia câtorva naivi, precum capitalismul nostru e un nume nou pentru vechea robie a celor mulţi de către o mână de indrăzneţi." Publicistul înfierează cu vigoare tendinţele politice şi culturale puternice ale vremii, de capitulare necondiţionată în faţa modelului occidental şi de renunţare la tradiţia naţională şi la valorile proprii: „Europenizatorii noştri cu orice preț au oroare de tradiție. De dragul lumii străine ar vrea să înnăbuşe glasul trecutului. Nu vor să lase tânărul suflet românesc să se

\footnotetext{
${ }^{23}$ idem, p. 215.

${ }^{24}$ ibidem.

${ }^{25}$ Liviu Rebreanu, Europensim sau Românism, în Opere. 16..., p. 220.

${ }^{26}$ ibidem, p. 526.
} 
dezvolte normal, ci se căznesc să-i lipească barbă şi mustăţi false, cărunte, să-l împopoţoneze cu straie gata făcute de alţii pentru alţii şi îşi închipuie că astfel sclivisiţi vor înşela lumea. Românismul pentru ei înseamnă şovinism, iar religiozitatea înseamnă prostie." 27

Foarte aproape de viziunea etnocratică a lui Crainic, anticipând chiar frenezia spirituală a generaţiei '30, în momentul afirmării ei prin Itinerariul spiritual al lui Eliade, Rebreanu are intuiţia unui destin auroral, marcat de puritatea spiritului tânăr, energic intrat pe făgaşurile cristalizării sale: „,Azi sufletul românesc descătuşat, tânăr, puternic, simte imperios nevoia e a se realiza în întregime, de a-şi împlini menirea ce $i$-a fost hărăzită. $" 28$

Viziunea exclusivistă a romancierului asupra „românismului” „,numai românismul poate fi aducător de cultură pentru noi" ${ }^{29}$ - implică emergenţa unor coordonate frecvente în opera publicistică a lui Rebreanu şi care constituie o bază a operei sale literare: tradiţia, religiozitatea, nu lipsită de un oarecare iz patriarhal, rămân în cadrele existenţei sale o constantă, deseori exprimată în articole sau notaţii precum $\hat{I n}$ ce cred?, Hristos a înviat! sau Puterea credinţei - în fond, universul tradiţional arhaic românesc. Tributar, într-o oarecare măsură, ideilor teoretice ale lui Nichifor Crainic, Rebreanu consideră că specificul naţional, denumit în epocă românism, îşi trage seva vitală tocmai din aceste valori permanente ale spiritualităţii autohtone: ,religiozitatea e tocmai trăsătura cea mai caracteristică a poporului românesc, că ea e însăşi temelia fiinţei noastre etnice şi naţionale"30. Creştinismul românesc (în speţă ortodoxismul şi „catolicismul unit” - aici prozatorul diferenţiidu-se de mentorul Gândirii) a dat coloratura specificităţii neamului, prin faptul că s-a constituit pe teren autohton, printr-un îndelung proces formativ, organic, interior, adaptat la ritmurile psiho-sociale ale mentalităţii colective, străvechi, arhaice: „Creştinismul nostru a luat culoarea noastră , s-a prefăcut în sângele nostru, s-a dospit în sufletul nostru. Invăţăturile lui Hristos s-au amestecat puţin cu credinţele străvechi, dând naştere unei religii anume pentru inima noastră."

În aceeaşi termeni este percepută şi tradiţia, sufletul unui neam ${ }^{32}$ care generează formele de manifestare ale acestuia, prin faptul că înmagazinează „, suma tuturor amintirilor, veşnic vie în subconştientul poporului, ${ }^{33}$ şi care devine astfel matricea creatoare a civilizaţiei ca "totalitate de forme ale vieţii unui popor, totdeauna specifice", în care să se reflecte imaginea

\footnotetext{
${ }^{27}$ Liviu Rebreanu, Europensim sau Românism, în Opere 16..., p. 221.

${ }^{28}$ Ibidem, p. 219.

${ }^{29}$ Ibidem, pp. 223-224.

${ }^{30}$ idem, Cumplita nesimţire religioasă a poporului nostru?, în Opere 16..., p. 218.

31 ibidem, p. 219.

${ }^{32}$ idem, Tradiţionalismul, în Opere 16..., p. 246.

33 ibidem.
} 
„sufletului acelui popor”. Respinsă cu asiduitate de moderniştii progresişti, de aceia care deplâng lipsa civilizaţiei, suprimând trecutul modest, lipsit de spectaculozitatea unui destin eroic, tradiţia reprezintă, în opinia publicistului, însuşi focarul prim al civilizaţiei. Ca urmare, în raportul dintre tradiţie şi civilizaţie, Rebreanu postulează primatul tradiţiei: „tradiţia singură creează civilizaţiile" care asigură înflorirea unei civilizaţii specifice, a cărei caracteristică elementară să fie „,culoarea românească”. ${ }^{34}$

Conştientizarea faptului că ,acum sufletul românesc trebuie să inceapă a-şi realiza viaţa" ${ }^{35}$, atrage după sine limpezirea perspectivelor de acţiune la nivelul mentalităţii şi al percepţiei colective asupra fenomenului românesc. Rebreanu resimte necesitatea unei schimbări în psihologia poporului care să reverbereze mai apoi în cadrul sistemelor politice şi sociale. Situaţiile critice ale politicii nu scapă de privirea analitică şi exploratoare a publicistului care constată cu pertinenţă că politica familiară în mediul căreia ,luptele politice româneşti utilizau negreşit violenţa verbală" şi ,,certurile erau vehemente şi permanente” trebuie eliminată din tabloul României de după Unire. Noile realităţi ale ţării reclamă necesitatea unor noi cadre ale vieţii politice, bazate, în primul rând, pe „o profundă seriozitate.” Autorul este conştient că „schimbarea nu se poate face de pe o zi pe alta. Intâi trebuie să se transforme însăşi mentalitatea noastră, care apoi va schimba fără îndoială sistemul" ${ }^{36}$ Ideea de schimbare a mentalităţii a creat o adevărată emulaţie în epocă, glisând uşor înspre noţiunea de om nou, pe care o întâlnim şi în dezbaterile polemice ale lui Eliade sau Cioran ori la ideologii dreptei naţionaliste. Luat ca atare, conceptul a dobândit un perimetru ideatic, mai mult speculativ, care ulterior, în concepţia extremei drepte legionare, s-a cristalizat în paradigmele unei misiuni primordiale, de mistică naţională, asumată cu fervoare. Conceptul va fi preluat de altfel şi de către ideologia de stânga a regimului comunist după instaurarea acestuia la cârma ţării. Revenind însă la începuturile vehiculării acestui termen pe teren românesc - el a fost exploatat la maximum în Europa, atât de către ideologia nazistă sau fascistă, cât şi de comunismul internaţional - se constată faptul că sensul său utopic în fond, vizează tocmai schimbarea din temelii a mentalităţii individuale şi colective, privite ca premise în dezvoltarea şi progresul social. De mare succes în rândurile intelectualilor vremii, noţiunea este percepută de fapt ca un rezultat imaginat în urma unor transformări interioare a individului, de natură psihologică, morală, spiritual religioasă care să construiască mai apoi o nouă atitudine socială. Aspectul este strâns legat de emanciparea tinerilor intelectuali ai generaţiei ' 30 care, cuprinşi de frenezia şi patosul trăirii experimentale, încercau o „revizuire de valori” şi depăşirea limitelor perimate ale vieţii sociale şi politice: „De abia acum

\footnotetext{
${ }^{34}$ ibidem, p. 247.

${ }^{35}$ idem, Europensim sau Românism, în Opere. 16..., p. 220.

${ }^{36}$ Liviu Rebreanu, Comploturi, în Opere. 16..., p. 256.
} 
incepe să fie înţeles sensul acestei revoluţii creştine, care încearcă să creeze o Românie nouă creând întâi un om nou, un creştin perfect - şi care inlocuieşte vechea "viaţă politică», printr-o "viaţă civilă», adică restaurează raporturi de omenie şi de creştinătate în sânul aceleiaşi comunităţi de sânge" ${ }^{\text {"37. }}$.

\footnotetext{
${ }^{37}$ Mircea Eliade, Texte «Legionare» şi despre «Românism», Editura Dacia, Cluj-Napoca, 2001, p. 51.
} 